\title{
環境保全型農業に向けた斑点米カメムシ類 の要防除水準について
}

藤田文彦・渡辺敏・石川千秋

(岐阜県病害虫防除所中濃支所)

岐阜県の中山間地域に位置する中濃地域は, 斑点米 カメムシの常発地域である。この被害を防止するため に出穂期, 乳熟期にそれぞれ 1 回の農薬散布が行われ ている。しかし, 環境保全型農業を展開する立場から は農薬散布は 1 回でも少なくすることが求められてお り, 防除法の再検討が必要となっている。このため, 平成 6 年度から, 発生するカメムシの種類, カメムシ 及び斑点米の発生状況，防除回数之斑点米発生の関係 について調查し, カメムシのすくい取り量から出穂期, 乳熟期の防除要否を検討した。

\section{試験方法}

\section{1 ）発生状況調査}

管内の巡回調査地点に斑点米が多発した地点を加党 た 9 地点において, 出穂期（7 月下旬）と乳熟期（8 月中旬）にすくい取り（反復）20回振法によりカメム シの発生状況を調査し, 収穫期（9月中旬）に斑点米 の発生状況を調査した。

\section{2 ) 防除試験}

出穂期, 乳熟期各 1 回の慣行 2 回防除区（出穂期 : ジメチルビンホス $2 \%$ 粉阂, 乳熟期 : ME P 3\%粉剂) に対し, 出穂直前 1 回防除区, 乳熟期 1 回防除区及び 無防除区（各区 2 a ）を設け，カメムシの種類，生息 数及び斑点米の発生状況を調査した。また，各区には 寒冷紗による被覆株（各 8 株）を設け，県内で防除の めやすとなっている乳熟期 0.75 頭／株（6 頭）を基準 にして，0.5頭／株（4頭）及び1.0頭／株（8頭）の クモへリカメムシを散布前日に放飼し, 薬剂散布後は 慣行管理を行い, 収穫後に斑点米の発生状況を調査し た。

圃場内のカメムシ発生状況は薬剂散布前後にすくい 取り20回振法で調查し, 斑点米は各区任意の50株から 抜き取った 50 穂と寒冷紗で被覆した 8 株の全穂で調査 した。

\footnotetext{
結果

中濃地域で発生したカメムシの種類は, クモヘリカ
}

メムシ, ホソハリカメムシ, トゲシラホシカメムシ及 びアカヒメヘリカメムシの 4 種であった。過去この地 域の優占種は昭和 50 年当時はアカヒメヘリカメムシ, 昭和 60 年代はホソハリカメムシであったが, 今回の調 査ではクモへリカメムシであった。

カメムシの発生量は, 早生種が穂ばらみ期を迎えた 7 月中旬に各圃場で見られるようになり，7月下旬に は $0 \sim 19.3$ 頭, 平均 5.1 頭, 乳熟期の 8 月中旬は $0.9 \sim$ 11.0 頭, 平均8.6頭と増加した。この発生量は, $1 \mathrm{~m}^{2}$ 当たりの植付株数 22 株, 20 回振当たりの推定面積を $13.2 \mathrm{~m}^{2}$, 圃場におけるすくい取り効率を $15 \%$ として 算出すると, 出穂期の平均は $1 \mathrm{~m}^{2}$ 当たり約 2.6 頭, 8 株当たり (22株 $/ \mathrm{m}^{2}$ 植え) 1.0 頭となり, 同様に乳熟 期の平均は $1 \mathrm{~m}^{2}$ 当たり約 4.3 頭, 8 株当たり 1.6 頭と 推定された。

9 地点の斑点米率の平均は, 精玄米 $0.47 \%$, くず米 $13.04 \%$, 総粒数 $0.73 \%$, 全ての地点で斑点米が発 生していた。

解析戋場のカメムシ数は, 散布前のすくい取り20回 振で出穂直前 $0.5 \sim 3.0$ 頭, 乳熟期 $1.0 \sim 7.0$ 頭であった が, 両時期とも防除 1 日後には半分以下に減少した。 しかし，3 日後には再び増加した。（第 1 表）

各区の総粒数に対する斑点米率は, 慣行 2 回防除 $0.50 \%$ に対し, 出穂直前 1 回防除 $0.58 \%$, 乳熟期 1 回 防除 $0.50 \%$ と同等であった。（第 2 表）

解析圃場の被覆株の放飼頭数 0.5 頭／株，0.75頭／ 株及び 1.0 頭/株は，すくい取り 20 回振面積に換算す ると, それぞれ21.8頭, 32.7頭, 43.6頭の発生頭数で, この出穗直前 1 回防除, 乳熟期 1 回防除及び慣行 2 回 防除の頭数別平均斑点米率は, 無防除 $13.16 \%$ に対し, $0.82 \% ， 0.66 \% ， 0.54 \%$ と各区とも高い防除効果が認 められ乳熟期 1 回防除の効果が最も高かった。（第 3 表)

頭数が増加した場合の斑点米率の発生状況を精玄米 でみると，基準とした0.75頭／株に対し，0.5頭／株

Fumihiko FunitA, Satoshi WatANABE* and Chiaki IsHIKAWA (Chuno branch of Gifu Pl. Prot. Office, ${ }^{*}$ Gifu $\mathrm{Pl}$. Prot. Office):Investigation of control threshold level of rice bugs for conservation of environment and sustainable agriculture.

1995年12月18日受理 
は 1/4〜1/20発生であったが，1.0頭／株にな ると1.6〜2.8倍となり, 発生量が多くなった場合には 防除効果が低下した。また，頭数が 1.0 頭／株にもな ると斑点米率は慣行 2 回防除でも $0.87 \%$ と出荷検査規 格上限の $0.7 \%$ 超える高率となった。（第 3 表）

\section{考察}

中濃地域における斑点米カメムシは，クモヘリカメ ムシを主体とする 4 種である。この発生要因としては 早生種への品種変化, 休耕田・転作飼料田の増加及び 晆畔雑草の放任等が関係していると考えられる。また，

第 1 表 薬羭散布前後のカメムシ類発生状況（20回すくい取り調查）

\begin{tabular}{|c|c|c|c|c|c|c|c|}
\hline \multirow[b]{2}{*}{ 試 } & \multirow[b]{2}{*}{ 験 } & \multicolumn{3}{|c|}{ 出穂期 } & \multicolumn{3}{|c|}{ 乳熟期 } \\
\hline & & $\begin{array}{l}\text { 散布前 } \\
(8 / 9)\end{array}$ & $\begin{array}{l}1 \text { 日後 } \\
(8 / 10)\end{array}$ & $\begin{array}{l}3 \text { 星 } \\
(8 / 12)\end{array}$ & $\begin{array}{l}\text { 敬布前 } \\
(8 / 23)\end{array}$ & $\begin{array}{l}1 \text { 日後 } \\
(8 / 24)\end{array}$ & $\begin{array}{l}\text { 3日後 } \\
(8 / 26)\end{array}$ \\
\hline 出穂直 & 前 1 回防除 & 2.5 & 0 & 2.0 & 6.5 & 3.5 & 4.0 \\
\hline 乳熟其 & 月 1 回防除 & - & - & - & 1.0 & 1.0 & 0 \\
\hline 慣行 & 2 回防除 & 3.0 & 0.5 & 1.0 & 7.0 & 0 & 1.0 \\
\hline 無 & 除 & 0.5 & 2.0 & 3.5 & 7.0 & 2.5 & 4.0 \\
\hline
\end{tabular}

圃場内の発生は出穂期の早まりに伴い 7 月中旬に成虫 が飛来して始まり，更に 8 月中旬の乳熟期には新生虫 も加わってピークとなり，刚り取り時まで続くものと 思われる。これにより斑点米が高率に発生しており， 防除の重要性は今も変わっていない状況である。

防除実施のめや（要防除水準）は，被覆試験の結 果では防除を行った場合 0.75 頭/株は精玄米は出荷検 查規格の 3 等米 $(0.3 \%)$ に, 0.5 頭 $/$ 株は $1 \sim 2$ 等米 の範囲に入る。したがって，クモへリカメムシが優占 種となった今日の要防除水準は，これまでの0.75頭よ り少ない 0.5 頭／株となり，午前10時頃の条件下のす くい取り20回振で21頭付近と推定され，散布前の調査 でこれ以下なら出穗期防除を取りやめても 2 等米以上 の生産が期待できる。なお, カメムシは固場周辺から 飛び込んでくることや新生虫による加害が大きいこと から，出穂期の防除を省略した場合は乳熟期防除が重 要となる。

第 2 表 防除回数別斑点米発生状況（50穗抜き取り調査）

\begin{tabular}{|c|c|c|c|c|c|c|c|c|c|c|}
\hline \multirow{2}{*}{ 試 験 区 } & \multicolumn{3}{|c|}{ 精玄米 } & \multicolumn{3}{|c|}{ くず米 } & \multicolumn{3}{|c|}{ 総粒数 } & \multirow[b]{2}{*}{ 防除価 } \\
\hline & 総粒数 & $\begin{array}{l}\text { 斑点米 } \\
\text { 粒 数 }\end{array}$ & $\begin{array}{l}\text { 斑点米 } \\
\text { 率 }(\%)\end{array}$ & 総粒数 & $\begin{array}{l}\text { 斑点米 } \\
\text { 粒 数 }\end{array}$ & $\begin{array}{l}\text { 斑点米 } \\
\text { 率 }(\%)\end{array}$ & 総粒数 & $\begin{array}{l}\text { 斑点米 } \\
\text { 粒 数 }\end{array}$ & $\begin{array}{l}\text { 斑点米 } \\
\text { 率(\%) }\end{array}$ & \\
\hline 出穗值前 1 回防除 & 4187.5 & 19.5 & 0.46 & 94.5 & 5.5 & 5.82 & 4282.0 & 25.0 & 0.58 & 72.6 \\
\hline 乳熟期 1 回防除 & 3877.0 & 15.0 & 0.41 & 163.0 & 4.5 & 2.76 & 4040.0 & 19.5 & 0.50 & 76.4 \\
\hline 慣行 2 回防除 & 4115.0 & 14.0 & 0.34 & 113.5 & 4.5 & 4.00 & 4228.5 & 21.0 & 0.50 & 76.4 \\
\hline 防 & 4341.5 & 84.0 & 1.93 & 154.0 & 8.0 & 5.19 & 4495.5 & 92.0 & 2.12 & - \\
\hline
\end{tabular}

第 3 表 カメムシ頭数別防除回数別斑点米発生状況（8株刈取り調査）

\begin{tabular}{|c|c|c|c|c|c|c|c|c|c|}
\hline \multirow[b]{2}{*}{ 試 験 区 } & \multirow{2}{*}{$\begin{array}{c}\text { 放飼 } \\
\text { 頭数 } \\
\text { (頭数/8株) }\end{array}$} & \multicolumn{3}{|c|}{ 精玄米 } & \multicolumn{3}{|c|}{ 総粒数 } & \multirow{2}{*}{$\begin{array}{c}3 \text { 区平均 } \\
\text { 斑点米率 } \\
(\%)\end{array}$} & \multirow[b]{2}{*}{$\begin{array}{l}\text { 刈取時の } \\
\text { 新生虫数 }\end{array}$} \\
\hline & & 総粒数 & $\begin{array}{l}\text { 斑点米 } \\
\text { 粒 }\end{array}$ & $\begin{array}{l}\text { 斑点米 } \\
\text { 率(\%) }\end{array}$ & 総粒数 & $\begin{array}{l}\text { 斑点米 } \\
\text { 粒 数 }\end{array}$ & $\begin{array}{l}\text { 斑点米 } \\
\text { 率(\%) }\end{array}$ & & \\
\hline \multirow[t]{3}{*}{ 出穂直前 1 回防除 } & 4.0 & 4282.0 & 9.0 & 0.21 & 4600.5 & 12.0 & 0.27 & & 0 \\
\hline & 6.0 & 3197.0 & 17.0 & 0.42 & 3910.0 & 28.0 & 0.59 & & 0 \\
\hline & 8.0 & 4065.0 & 48.3 & 1.19 & 4917.5 & 78.0 & 1.59 & 0.82 & 4.5 \\
\hline \multirow[t]{3}{*}{ 乳熟期 1 回防除 } & 4.0 & 5277.5 & 8.5 & 0.16 & 5818.5 & 12.0 & 0.20 & & 0 \\
\hline & 6.0 & 5174.0 & 33.5 & 0.65 & 5670.5 & 34.0 & 0.69 & & 3.5 \\
\hline & 8.0 & 4789.5 & 50.0 & 1.01 & 5324.0 & 61.0 & 1.09 & 0.66 & 0 \\
\hline \multirow{3}{*}{ 慣行 2 回防除 } & 4.0 & 4837.5 & 3.5 & 0.08 & 5284.0 & 8.5 & 0.16 & & 0 \\
\hline & 6.0 & 4819.5 & 14.0 & 0.31 & 5164.5 & 22.0 & 0.43 & & 0 \\
\hline & 8.0 & 5450.5 & 51.0 & 0.87 & 5766.0 & 59.0 & 1.04 & 0.54 & 0 \\
\hline \multirow[t]{3}{*}{ 無 } & 4.0 & 4351.0 & 640.5 & 16.71 & 4500.5 & 952.5 & 21.27 & & 45.5 \\
\hline & 6.0 & 4318.0 & 318.0 & 6.61 & 5203.5 & 486.5 & 8.94 & & 16.5 \\
\hline & 8.0 & 3603.0 & 223.5 & 5.76 & 4640.0 & 340.0 & 9.27 & 13.16 & 22.5 \\
\hline
\end{tabular}

